FINAL TECHNICAL REPORT

October 1, 1998 - August 31, 2001

\title{
ALLIANCE FOR COMPUTATIONAL SCIENCE COLLABORATION
}

HBCU Partnership at Tennessee State University

\author{
Grant Number: \\ DE-FG02-98ER25368 \\ Submitted by: \\ FG02-98ER25368 \\ Dr. Sandra Scheick, Project Leader

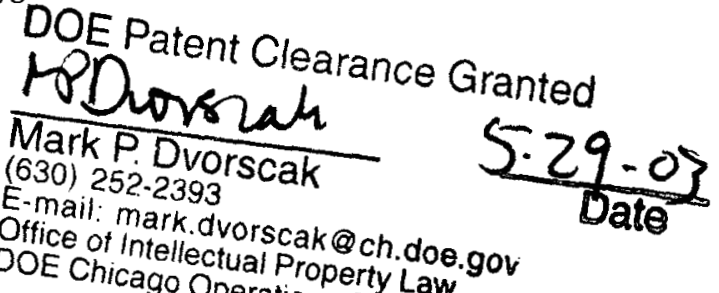 \\ Department of Mathematics \\ 3500 John A. Merritt Boulevard \\ Nashville, TN 37209-1561 \\ Phone: 615.963 .5811 \\ FAX: 615.963 .5099 \\ Email: sscheick@tnstate.edu
}

Submitted to:

Dr. Daniel Hitchcock

Department of Energy

Mathematical, Information, and Computational Sciences Division

In Cooperation with:

Oak Ridge National Laboratory

University of Tennessee, Knoxville

Krell Institute 


\section{DISCLAIMER}

This report was prepared as an account of work sponsored by an agency of the United States Government. Neither the United States Government nor any agency Thereof, nor any of their employees, makes any warranty, express or implied, or assumes any legal liability or responsibility for the accuracy, completeness, or usefulness of any information, apparatus, product, or process disclosed, or represents that its use would not infringe privately owned rights. Reference herein to any specific commercial product, process, or service by trade name, trademark, manufacturer, or otherwise does not necessarily constitute or imply its endorsement, recommendation, or favoring by the United States Government or any agency thereof. The views and opinions of authors expressed herein do not necessarily state or reflect those of the United States Government or any agency thereof. 


\section{DISCLAIMER}

Portions of this document may be illegible in electronic image products. Images are produced from the best available original document. 


\section{ALLIANCE MISSION AND GOALS}

In October, 1997 Oak Ridge National Laboratory (ORNL), the Joint Institute for Computational Science (JICS) at the University of Tennessee, Knoxville (UTK), and the Krell Institute (Krell) established an alliance with two Historically Black Colleges and Universities (HBCUs)--Tennessee State University (TSU) and Fisk University (Fisk) in Nashville, TN. In 1998 this alliance expanded to include Alabama A\&M University (AAMU) in Huntsville, AL. And in 1999, Spelman College in Atlanta, GA joined the alliance.

The mission of this alliance is to promote, encourage, and facilitate computational science activities at the member HBCUs and to use collaborative technologies among the alliance partners to create an environment in which students and researchers from a wide variety of applications areas can exchange ideas and share resources.

An overall project goal is to increase the number of minority students who receive undergraduate, masters, and doctorate degrees in computer science, mathematics, engineering, and the biological and physical sciences, with the expectation that DOE national laboratories will ultimately employ many of these minority students. Specific objectives to accomplish this overall goal are:

1) To involve HBCU students and faculty members in computational science projects at national laboratories and research institutions;

2) To facilitate collaborative research among students and researchers at ORNL, UTK, and the HBCU partners;

3) To assist HBCU faculty members in integrating interdisciplinary computational science courses into their undergraduate curricula; and 
4) To set up parallel processing laboratories that are designated for student use, with knowledgeable help available for the students.

\section{OUTCOMES}

Dr. Phillip Ollapally left Tennessee State University in the fall of 1999, but has continued to supervise the students who administrate the departmental server as well as providing assistance to the program as needed. Our attempt at building a virtual machine using IIci Macintosh's has not faired well, but we are still trying.

Dr. Yong X. Tao left Tennessee State University in the spring of 2000 and Dr. Scheick recruited Dr. Frank Allen, Dr. Toby Anderson, and Dr. Thomas Taylor into the program. They attended workshops at the Joint Institute for Computational Science (JICS) during the summer of 2000. Dr Taylor is planning to reestablish a previous research connection that he had with Oak Ridge.

Three students, Miss Tianisha Simmons, Mr. Byron Davis and Mr. Chauncey Williams participated in the Summer Internship Programs at the Oak Ridge National Laboratory. Miss Simmons graduated as a mathematics major in the spring of 2001 and is now in graduate school. Miss Simmons, based on what she had gained from her ORNL experience, assisted many of the faculty in setting up websites. Mr. Davis works as one of the departmental server administrators.

The Department of Physics and Mathematics at Tennessee State University has a small computing laboratory, consisting of an assortment of Macintosh computers: six Power Mac's 6100/66, twelve Performa's 6115CD, three G3's and the not yet functional virtual Mac (twenty four linked IIci's). In this lab we are currently teaching several of the upper division and graduate mathematics courses. Also, this lab is the simulation laboratory for our newly established astronomy program as well as the laboratory for the computer science logic design course. 


\section{EPILOGUE}

In the fall of 2001 Tennessee State University decided to consolidate all of the computing services at the university. As a result, our departmental server and laboratory became known. Although we were not allowed to continue having our own server, all our student administrators we hired to work with the university server. Thanks to Dr. Ollapally they were very well trained.

Our computing laboratory was zoned essential and since then we have been receiving support from both the university and one of the Center's of Excellence here on campus. Our computing laboratory now has twenty-two G4 Macintosh computers (linked) and one not very functional virtual Mac (twenty four linked IIci's). At Tennessee State we don't give up easily. We are continuing on the paths that we started back in 1997.

Mr. Bryon Davis will be graduating in the summer of 2003 with a triple major; physics, mathematics, and computer science. Also, Mr. Chauncy Williams will be graduating in the summer of 2003 with a double major; mathematics and computer science. Graduate school is in both of their plans. 